FACTA UNIVERSITATIS

Series: Economics and Organization Vol. 18, No 4, Special Issue, 2021, pp. 397 - 406

https://doi.org/10.22190/FUEO210730028B

Original Scientific Paper

\title{
THE PANDEMIC WAVES' IMPACT ON ROMANIAN E-MARKET: A NON-LINEAR REGRESSION MODEL
}

\author{
UDC 616.98:578.834 \\ 004.738.5:339
}

\section{Costin Radu Boldea ${ }^{1}$, Bogdan Ion Boldea ${ }^{2}$}

\author{
${ }^{1}$ University of Craiova, Craiova, Romania \\ ${ }^{2}$ West University of Timisoara, Timisoara, Romania
}

ORCID iD: Costin Radu Boldea $\quad$ (1) N/A

Bogdan Ion Boldea $\quad$ (i) N/A

\begin{abstract}
The SARS-COV2 pandemic had a strong impact on the Romanian and European e-Market, manifested by the explosive increase in online sales, especially at the beginning of the two waves of epidemic, in spring and autumn. Using a statistical regressive analysis of monthly change in the volume of online sales in Romania, we propose a non-linear regression model of growth of this commercial sector that take into account the economic and socials effects of the three pandemic waves in 2020-2021, combining logistic equations of growth with attenuated quasi-periodical variations of market. The model allows a prediction of the overall behavior of online buyers for 2021 and 2022, similar to last year, but with annual growth peaks slightly less pronounced than in 2020.
\end{abstract}

Key words: E-market, Non-linear regression model, post-pandemic market behaviour

JEL Classification: C51, C53

\section{INTRODUCTION}

The crisis produced by the spread of COVID-19 has severely affected the world both in terms of health and economics. The actions to prevent and combat it, such as social distancing and closing non-essential businesses, have significantly changed the lifestyle of the population.

Received July 30, 2021 / Revised October 02 / Accepted November 05, 2021

Corresponding author: Costin Radu Boldea

University of Craiova Al.I. Cuza Street, No. 13, Craiova RO-200585, Romania |E-mail: cboldea@inf.ucv.ro

ㄷ 2021 by University of Niš, Serbia | Creative Commons Licence: CC BY-NC-ND 
E-commerce refers to both online commerce and electronic transactions. It has greatly increased its popularity in recent decades and it is beginning to increasingly replace traditional stores. An e-commerce allows you to sell and buy products 24 hours a day, without having to be physically present in a traditional store. While many people think of e-commerce as business to consumer (B2C), there are many other types of e-commerce. These include online auction sites, internet banking, online tickets, reservations and business to business (B2B) transactions. Recently, e-commerce has expanded through sales using mobile devices, known as "m-Commerce".

The e-consumers' comportment is one of the most transformed behaviors after the spread of COVID-19 pandemic situation. With limited access to physical shopping areas and the potential danger of going outside, e-commerce has become the retail alternative of choice for the entire European population. The evolution of purchasing behavior in this time of crisis follows the logic of Maslow's pyramid of needs, which classifies human needs in order of importance. To meet their physiological and safety needs (at the base of the pyramid), consumers are mainly supplied with food and pharmaceuticals; they make sure they have the basic equipment to stay at home (electronic devices) and save on funds allocated to holidays or products of luxury.

E-commerce largely contributes to increasing globalization. The crystallization of a global network-based market has the advantage of removing the restrictions imposed by traditional trade. If they also take into account the low costs involved in an electronic business transaction, company managers must prefer such a market that provides them with substantial profits (Boldea 2010a).

The development of e-commerce offers unique opportunities to reorganize business, redefine markets or create new markets. E-commerce initiatives will influence cost reductions, revenue increases and greater efficiency for companies looking to gain an edge in today's competitive environment in light of the COVID-19 pandemic.

From a macroeconomic point of view at a Central Bank, the M0 Monetary Base, the money multiplier, and the M1, restricted money supply, will be severely affected by the development of e-commerce, leading to a significant decrease in primary currency issuance, and hence, the blocking of the transmission of monetary policy through monetary control. This reality also determines the diminution of the right of secrecy of the Central Bank, with a blocking of the actions influencing the main macroeconomic indicators - mainly the financial intermediation, the exchange rate, the balance of payments and the current capital account (Boldea 2010b).

For all these reasons, the study of effects and evolution of e-commerce in next short and medium term is very important in this period.

This paper examines the evolution of e-commerce observed in the Romanian retail sector in 2020, trying to propose a nonlinear statistical model with three components: main trend, explosion due to reduction of non-essential businesses and distancing restrictions, modeled by logistic components, and seasonal evolution, due to consumers' social reaction, of Romanian e-commerce market in 2020. The choice of this kind of model is justified by the increase in the number of users of electronic means of payment in various European countries, the diversification of the supply of traders and distributors, as well as the slower return to the classic system of purchases of consumer goods directly from stores by consumers already accustomed to the e-market.

After this introduction, we present a brief review of previous studies on the impact of the COVID-19 pandemic on e-commerce and the economy in general. The third section is dedicated to the presentation of our model of the global variation concerning the E- 
market after the successive pandemic waves, followed by an interpretation section of the model in view of its applicability for economic forecasts. The article ends with some personal conclusions of the authors.

\section{PREVIOUS STUdIES ON THE IMPACT OF THE SARS-COV2 PANDEMIC ON E-MARKET}

The SARS-COV2 pandemic spread extremely fast, with two successive waves in 2020 and a third in 2021, forcing the governments to impose isolation measure as well as the closure of many non-essential businesses. The result of these social and economic restriction produces major changes in the behavior of current consumption in households, as well as changing the way retail customers make their purchases. Baker, Farrokhnia, Meyer, Pagel and Yannelis, (2020) analyzed these effects for the case of USA, (Dou et al. 2020) for the case of China, and (Ker \& Cardwell 2020) for Canada.

Starting from March 2020, new measures to slow the spread of COVID-19 had a significant impact on the way consumers shop in retail. As companies reduced or changed their operations in traditional stores, consumers were also called upon to practice physical distance, with the option of shopping online to become an important alternative to shopping in-person.

The vast majority of governments have adopted social distance measures, imposed blockades and temporarily closed certain businesses considered non-vital.

All this has led to a growth in the online shopping market, as well as an increased demand for a wide range of digital services, with many consumers opting for purchases made either via the Internet or by telephone. Several traditional companies have redirected their resources to e-commerce. "The increase in the number of consumers using digital services has led digital service providers and telecommunications operators to strengthen their network capacity and provide cheap or even free data sets and services" (WTO, 2020). An exhaustive study on the impact of pandemic on the economic policy of governments was published at the end of 2020 (Chen, Igan, Pierri \& Presbitero, 2020).

From February to May 2020, the total retail sales in Europe fell by $17.9 \%$. However, e-commerce retail sales almost tripled $(+174 \%)$, with some retailers relying more on this method of sale than on the classic version (Wix E-commerce, 2020). The economic crisis generated by COVID-19 pandemic is expected to strongly affect many sectors of activities (such as health, education, living standard) of the developing countries (Barbier E \& Bugess J. 2020), retarding the achievements of several Sustainable Development Goals (SDGs) (Shulla, K., 2021).

A comparative study between multiple country about the pandemic effect on the retail market was published by the Bank for International Settlements (Alfonso, Boar, Frost, Gambacorta \& Liu, 2021), stating that "the growth of e-commerce has been higher in countries where there were more stringent containment measures and where e-commerce was initially less developed, and the changes in consumers' shopping habits and payment behavior may be longer-lasting".

A first regression model of the social and economic consequences of the e-market behavior was proposed in December 2020 (Kokh, J., Frommeyer, B, \& Schewe, G, 2021). It is a structural equation multiple linear model, derived from four statistical hypothesis verified by authors.

We propose in this paper another non-linear model with higher correlation coefficient between predicted and observed global amounts of retail market, for the case of Romania. 


\section{The Proposed REgRession Model of E-MARKET BeHAVIOUR}

The evolution of online sales in Romania also experienced an upward trend in the year of the Pandemic, less pronounced than in other European countries, partly due to the lower spread means of electronic payment or even Internet access to the elderly or rural population. Fig. 1 presents the variation of monthly online retail sales in Romania, expressed in millions of euros, starting from the average monthly level of 2019: 360 million Euros (Iqads, 2020). It should be noted the existence of two peaks of strong growth of e-commerce corresponding to anti-COVID19 restrictions related to the two epidemic waves in spring (March-May) and autumn (September-December).

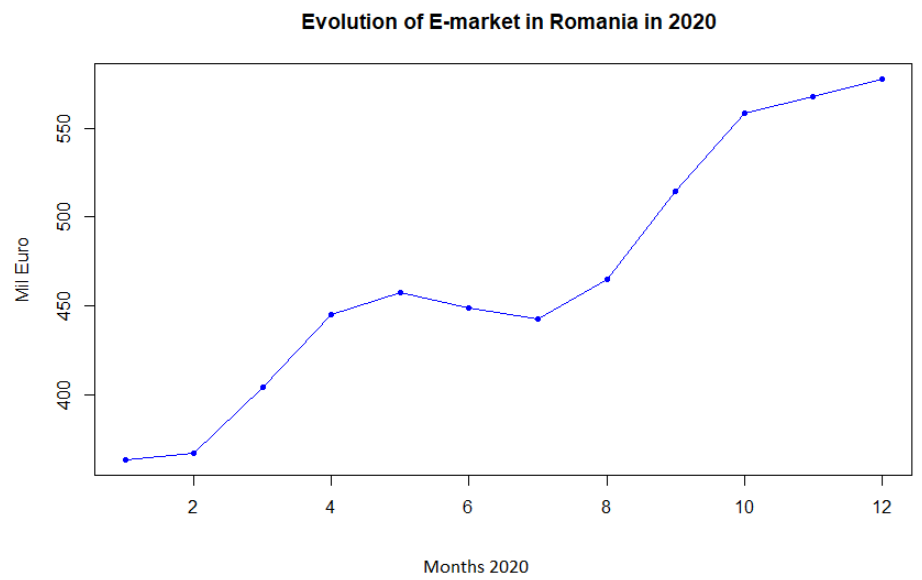

Fig. 1 The evolution of online sales in Romania in 2020, compared to the average monthly value (Euro mill. 360) in 2019

Data source: Eurostat 2021

The reduction in online sales during the summer is justifiable in terms of reducing government anti-epidemic restrictions. Statistically, the Romanian online retail trade reached Euro bill. 5.6 at the end of 2020, with growth peaks of $27 \%$ in May and $60 \%$ in December 2020, compared to the average monthly level from 2019.

The future evolution of this economic sector will also see increases based on the accustoming of the population to electronic means of payment, even in the absence of pandemic restrictions, as well as on the expansion of this market to the level of the European Union. But the growth of the e-commerce sector is not linear, being influenced by the European trend, seasonal variations and possible new waves of epidemics.

In this context, our research starts from the hypothesis:

(H1) The effect of a Pandemic crisis can be positively related to the global increase of sales in e-Market.

For testing this hypothesis, we chose to analyse a possible regression model based on asymtotical bouded logistical grothw equation. The second hypothesis was:

(H2) The effect of a Pandemic crisis can be positively related to the accentuation of seasonal variation of e-Market. 
The second hypothesis was tested using a Fisher statistical test on the regression equation, including various quasiperiodical terms. In general, an F-test (Fisher) in regression compares the fits of different models. Unlike T-tests (Student) that can assess only one regression coefficient at a time, the F-test can assess multiple coefficients simultaneously.

In order to compute the coefficients of the non-linear regression, we used an implementation of NLStool package under R language, a high performant statistical programming language (see Baty 2015 for a reference documentation).

In our model design, from the beginning we excluded the variant of a uniform growth of the economic sector of online sales, given the instability caused by the Pandemic. The main trend is obtained directly from the linear regression on the raw data of the variation of online trade in Romania

$$
\text { Sell }(\%) \sim-5.48+5.47 * \mathrm{M}
$$

where Sell represents the percentage of online sales growth compared to the average monthly value in 2019 , and $\mathrm{M}$ is the time factor expressed in months, which represents an average monthly increase of $5.47 \%$, with an error of $0.48 \%$ and the confidence factor $\mathrm{R}^{2}$ $=0.92$.

First we tested the hypothesis that the main effect of the pandemic crisis on the emarket behavior can be modeled by introduction of a new asymptotic term described by a logistic asymptotic equation, a model induced by the sudden change of interest in the online sale of current products, inspired by a previous work (Boldea \& Boldea 2012):

$$
\text { Sell }(\%) \sim[\mathrm{c} 0+\mathrm{c} 1 * \mathrm{M}]+[\mathrm{c} 2 /(0.5+\exp (\mathrm{c} 3 *(\mathrm{M}-\mathrm{c} 4)))]
$$

We obtain the coefficient estimation of the model using the facilities of $\mathrm{R}$ language, the NLS package.

$$
\mathrm{c} 0 \sim-1.76, \mathrm{c} 1 \sim 4.211, \mathrm{c} 2 \sim 6.074, \mathrm{c} 3 \sim-0.91, \mathrm{c} 4 \sim 7.5
$$

The model has a residual error 5.793 on 8 degrees of freedom and passes the Fisher test of significance with an F-coefficient $=63.59$. The correlation coefficient between the real Sell data and the prediction of model (2) is Correl $_{\mathbf{1}} \mathbf{= 0 . 9 6 6}$. The model is represented in Fig. 2.

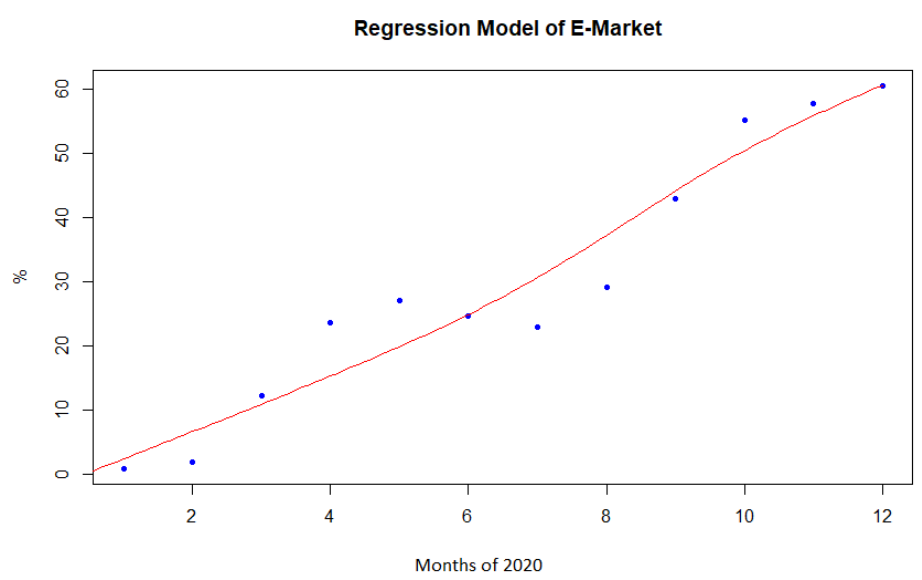

Fig. 2 The logistic regression model of online sales growth in Romania in 2020, compared to the average monthly value in 2019 
In the second part, we introduced a seasonal factor related to the more pronounced variation of sales in the period corresponding to the Easter or winter holidays. Besides this, although the original data covers only 2020 year, we introduced a new logistic term in order to simulate the effects of the third wave of pandemic in 2021. The final model therefore contains three components:

$$
\begin{array}{r}
\text { Sell }(\%) \sim[\mathrm{c} 0+\mathrm{c} 1 * \mathrm{M}]+[\mathrm{c} 2 /(0.5+\exp (\mathrm{c} 3 *(\mathrm{M}-7.5)))]+ \\
\mathrm{c} 5 .[\sin (\pi / 3 *(\mathrm{M}-\mathrm{c} 6)) /(\exp ((\mathrm{M}-\mathrm{c} 7) / 12))]]+[\mathrm{c} 4 /(0.5+\exp (\mathrm{c} 3 *(\mathrm{M}-15.5)))]+
\end{array}
$$

where the third factor, bi-annual seasonal, has a slow exponential decline in variation over time, based on the assumption that the effect of the Pandemic in 2021 and 2022 will be much smaller due to intensive vaccination campaigns. La last logistic term supposes that the maximum of the pandemic crisis was attained in the middle of April 2021. This factor models the consumer reaction to covid pandemic.

The coefficients of nonlinear Regression Model (3) were also obtained using the NLS nonlinear regression analysis package facilities from $\mathrm{R}$ language:

$\mathrm{c} 0 \sim 7.88, \mathrm{c} 1 \sim 2.03, \mathrm{c} 2 \sim 13.05, \mathrm{c} 3 \sim-0.91, \mathrm{c} 4 \sim 13.01, \mathrm{C} 5=9.91, \mathrm{c} 6 \sim 3.2, \mathrm{c} 7 \sim 3.01$

Regression Model of E-Market

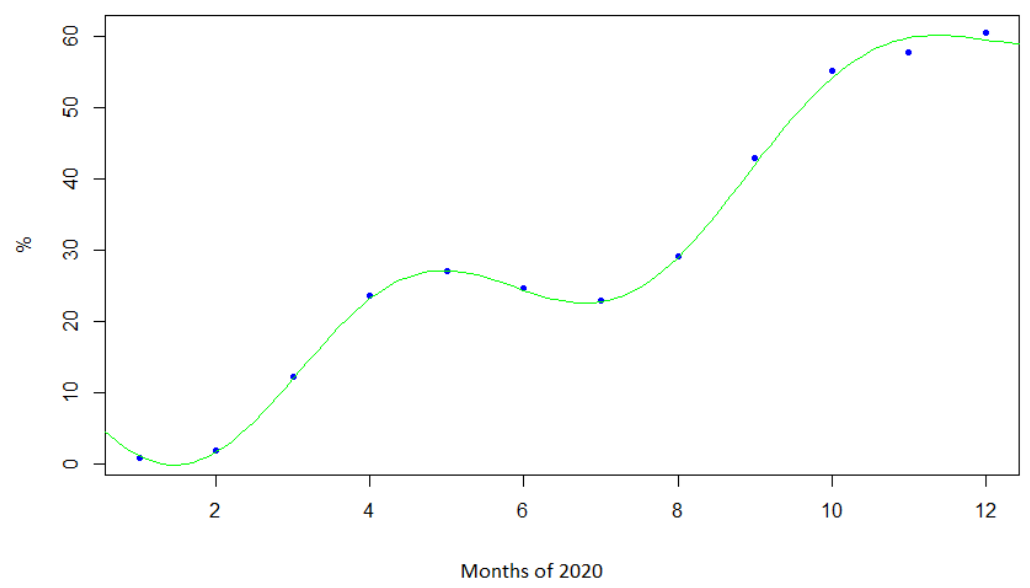

Fig. 3 Nonlinear regression model including seasonal quasi-cyclic factors and pandemic effect

The standard error of the model is $0.9226 \%$, the Fisher test of relevance being passed with $\mathrm{F}_{\text {calc }}=1341$, well above the significance limit, and the relevance coefficient of the model was $\mathrm{R}^{2}=0.998$; the correlation coefficient between the real Sell data and the prediction of model (2) is

$$
\text { Correl }_{2}=0.99934 \text {, }
$$

which represents a significantly higher value than in the case of logistic regression, undoubtedly allowing the use of this model in short- and medium-term predictions of the behavior of the online sales market in Romania. 


\section{THE FORECASTING OF THE MODEL AND INTERPRETATION}

Extending the simulation period of the model (3) by 24 months (Fig.4), we note the appearance of a phenomenon of constant growth of predictable online sales with an increasingly better-defined trend, having seasonal variations with growth peaks on the months of April-May, respectively October-December, economically significant as they correspond to the periods of maximum commercial activity induced culturally by the spring and winter holidays, respectively.

It should also be noted that this quasi-oscillating stretches with an average growth trend of $2.31 \%$ per month in the perspective of the next two years is justified by the growing interest of young people (aged 16-24) for e-commerce, according to the raw data at European level (Eurostat 2021, Fig.5).

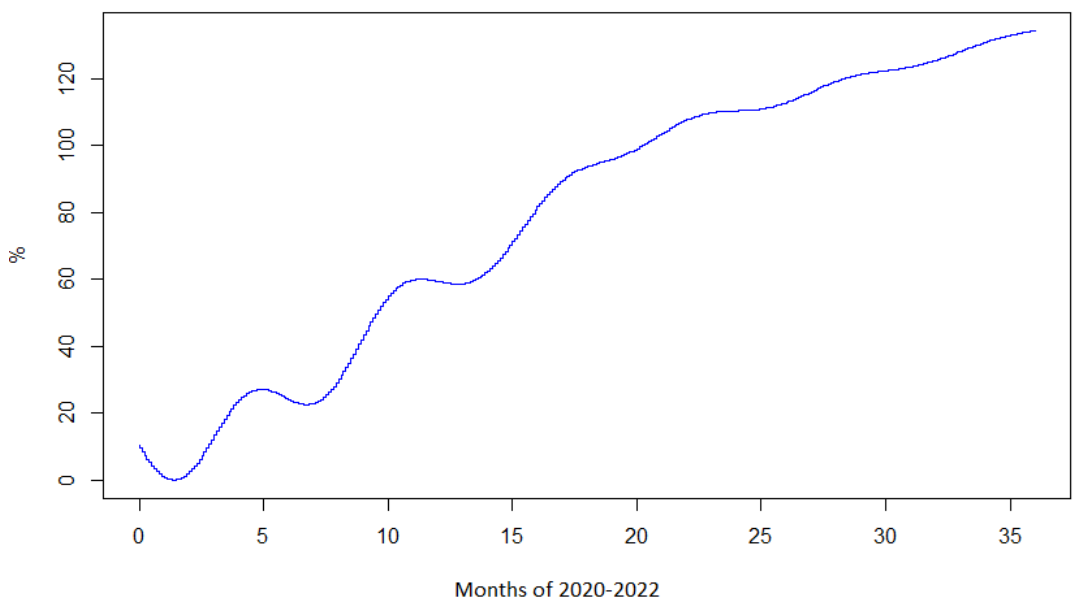

Fig. 4 The expected growth (in percent) of online sales in Romania in the period 20202022, compared to the average monthly value in 2019

One of the direct effects of pandemic restriction measures was the massive conversion of almost the entire young population (16-24 years old) to the massive use of the Internet, especially for online courses and socialization activities; given that over $78 \%$ of them use the electronic environment for shopping at least once a month, we can expect a doping effect on online commerce.

Thus, the seasonal component, strongly accentuated in 2020 (see Fig.5):

$$
\mathrm{Sell}_{2} \sim 9.91 * \sin (\pi / 3 *(\mathrm{M}-3.2)) /(\exp ((\mathrm{M}-3) / 12))
$$

with the two pronounced peaks of growth from April-May, respectively OctoberDecember, overlaps with the introduction of mandatory online courses for young people and social distancing restrictions, thus being amplified in 2020 by changing the social behavior of pupils, students, and young people in general.

The proposed model does not take into account any significant new waves of epidemic, given that we can expect a gradual return to normality after the massive vaccination campaign at European level, probably at the end of 2021. 


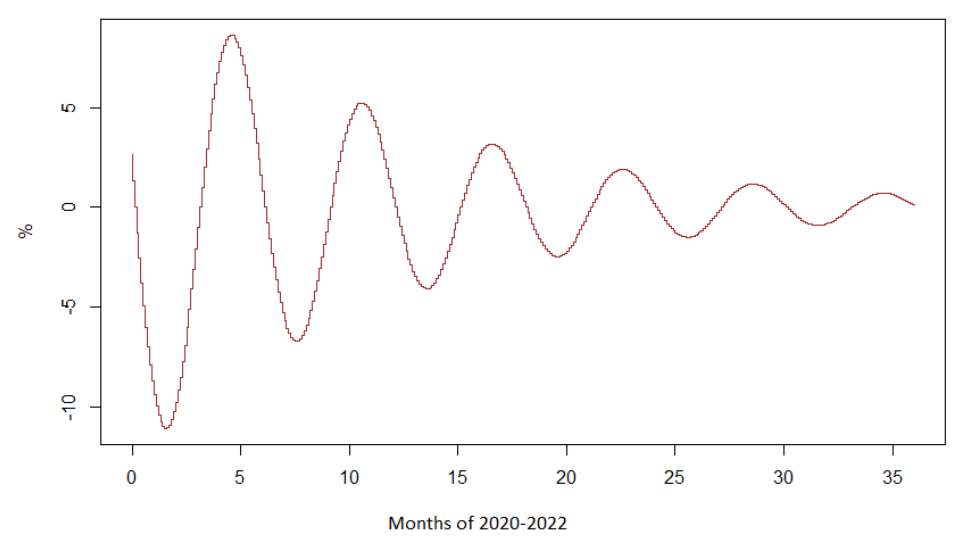

Fig. 5 The term of seasonal variation (in percentages) of online sales in Romania, related to the main trend of forecast growth of this sector in the period 2020-2022

According to our model, an increase in online commerce is expected until Euro mill. 610 per month in Romania, in April and May 2021, respectively exceeding Euro mill. 920 per month at the end of 2022, with 5\% marge of error. Taking into account the evolution of the European e-Market (WIX E-commerce 2020), Romanian e-commerce sector will continue to be below European average.

\section{CONCLUSIONS}

The model we propose in Section 3, based on the combination of online sales doping, driven by the effects of pandemic restrictions, with a natural seasonal effect - greatly amplified by the drastic change in the behavior of young shoppers in particular - has a relevance coefficient, respectively the correlation of the prediction with the real data, very high, both of over $99 \%$, the model being able to be used in predictions for the next two years of the e-Market of consumer products behavior. Following the results of this statistical study, we can say that the change in consumer behavior in the direction of ecommerce is irreversible, and the codifications that accelerated this trend during the pandemic are a natural evolution of e-Market.

However, the model proposed in this article did not take into account the impact of the vaccination campaign on consumers' dependence on online product sales (at the time of the study, the term "green passport" does not yet exist, with less benefits), as well as the emergence of new pandemic waves, much more virulent than the previous ones. The regressive model could be adjusted in the future in order to better adapt to their seasonal succession, given that a significant part of the population has already adapted to online commerce.

The current Pandemic situation will have a sustained impact on e-commerce even after the end of the pandemic restrictions, in several economic areas, not only those that include food and medication. The portrait of the online consumer has certainly changed, at least for now, forcing retailers to adapt to the new online market. There is no doubt that the Internet is about to become not only the new global electronic market on which the 
economic battle between the world's great powers is to take place, but also the means for the integration of small countries into the global economy of the 21 st century.

\section{REFERENCES}

Alfonso, V., Boar, C., Jon Frost, J., Gambacorta, L., \& Liu, J. (2021), E-commerce in the pandemic and beyond. BIS Bulletin, 36, Retrieved from: https://www.bis.org/publ/bisbull36.htm

Baker, S. R., Farrokhnia, R. A., Meyer, S., Pagel, M., \& Yannelis, C. (2020). How does household spending respond to an epidemic? Consumption during the 2020 covid-19 pandemic. Working Paper 26949. Retrieved from: http://www.nber.org/papers/w26949

Barbier E, \& Bugess J. (2020). Sustainability and development after COVID-19. World Development, 135. https://doi.org/10.1016/j.worlddev.2020.105082

Baty, F. et al., (2015). Tools for Nonlinear Regression Analysis, Preprint. Retrieved from: https://cran.r-project.org/ web/packages/nlstools/nlstools.pdf

Boldea, B. I. (2010a). Moneda electronică şi sistemele de plăţi electronice [Electronic money and electronic payments systems]. Timişoara: Ed. Mirton.

Boldea, B. I. (2010b). Efectele implementarii monedei electronice asupra politicii monetare [The effects of electronic money implementation on monetary policy]. Timişoara: Ed. Mirton.

Boldea, B. I., \& Boldea, C. R. (2012). The Financial Crisis Prediction using an Artificial Intelligence Method. Paradigme Social Sciences Journal, 6, 83-90.

Boldea, B. I. (2018). The Impact of Monetary Technologies Development on Sustainable Social Development. Ed. Joshua Print, Varset.

Chen, S., Igan, D. O., Pierri, N., \& Presbitero, A. F. (2020). Tracking the economic impact of COVID-19 and mitigation policies in Europe and the United States, IMF Working Paper, no 20/125. Retrieved from: https://www.imf.org/-/media/Files/Publications/WP/2020/English/wpiea2020125-print-pdf.ashx

Dou, Z., Stefanovski, D., Galligan, D., Lindem, M., Rozin, P., Chen, T., \& Chao, A. M. (2020). The COVID-19 Pandemic Impacting Household Food Dynamics: A Cross-National Comparison of China and the US. https://doi.org/10.31235/osf.io/64jwy

Eurostat Databases (2021). E-commerce statistics for individuals. Retrieved from: https://ec.europa.eu/eurostat/ statistics-explained/index.php/E-commerce_statistics_for_individuals

IQads (2020). Raport GPeC E-commerce România 2020 [GPeC E-commerce Report Romania 2020]. Retrieved from: https://www.iqads.ro/articol/53903/raport-gpec-e-commerce-romania-2020-cumparaturi-online-de-56-miliarde-de-euro

Ker, A. P., \& Cardwell, R. (2020). Introduction to the special issue on COVID-19 and the Canadian agriculture and food sectors: Thoughts from the pandemic onset. Canadian Journal of Agricultural Economics/Revue canadienne d'agroeconomie. (20200513). https://doi.org/10.1111/cjag.12245

Kokh, J., Frommeyer, B., \& Schewe, G. (2021). Online Shopping Motives during the COVID-19

Pandemic - Lessons from the Crisis, Sustainability 2020, 12, 10247. https://doi.org/10.3390/su122410247

Shulla, K. (2021). The COVID-19 pandemic and the achievement of the SDGs. Conference paper, Virtual Inter-agency Expert Group Meeting on Implementation of the Third United Nations Decade for the Eradication of Poverty (2018-2027) "Accelerating Global Actions for a World without Poverty”, Bonn 2427 May 2021. Retrieved from https://www.un.org/development/desa/dspd/wp-content/uploads/sites/22/ 2021/05/Shulla_paper1.pdf

United nations UNCTAD (2021). COVID-19 and e-commerce: a global review, Preprint. Retrieved from: https://unctad.org/webflyer/covid-19-and-e-commerce-global-review\#tab-2

World Trade Organisation (2020). E-commerce, Trade and the Covid-19 Pandemic, Information Report. Retrieved from: https://www.wto.org/english/tratop_e/covid19_e/ecommerce_report_e.pdf

WIX E-commerce (2020). 2020 L'annee du Ecommerce [The Year of Ecommerce], Retrieved from: https://fr.wix.com/ ecommerce/end-of-year-report?utm_source=ECN\&utm_medium=article\&utm_campaign=wix 


\section{UTICAJ PANDEMIČNIH TALASA NA RUMUNSKO E-TRŽIŠTE: MODEL NELINEARNE REGRESIJE}

Pandemija SARS-COV2 imala je snažan uticaj na rumunsko $i$ evropsko e-tržište, što se manifestovalo eksplozivnim porastom onlajn prodaje, posebno na početku dva talasa epidemije, $u$ proleće i jesen. Koristeći statističku regresivnu analizu mesečnih promena obima onlajn prodaje u Rumuniji, predlažemo model nelinearne regresije rasta ovog komercijalnog sektora koji uzima u obzir ekonomske $i$ socijalne efekte tri talasa pandemije u periodu 2020-2021., kombinujući logističke jednačine rasta sa oslabljenim kvaziperiodičnim varijacijama tržišta. Model omogućava predviđanje ukupnog ponašanja onlajn kupaca za 2021. i 2022. godinu, slično kao prošle godine, ali sa godišnjim vrhovima rasta nešto manje izraženim nego u 2020.

Ključne reči: E-tržište, model nelinearne regresije, ponašanje tržišta nakon pandemije 